\title{
Fertility Awareness-Based Methods Of Family Planning: Predictors of Correct Use
}

\author{
By Irit Sinai, \\ Rebecka \\ Lundgren, \\ Marcos \\ Arévalo and \\ Victoria Jennings \\ Irit Sinai is senior \\ research officer, \\ Rebecka Lundgren is \\ director of operations \\ and behavioral re- \\ search, Marcos \\ Arévalo is director of \\ biomedical research \\ and Victoria Jennings \\ is director, all at the \\ Institute for Reproduc- \\ tive Health, George- \\ town University, \\ Washington, DC.
}

\begin{abstract}
CONTEXT: Fertility awareness-based methods of family planning help women identify the days of the menstrual cycle when they are most likely to become pregnant. To prevent pregnancy, women avoid unprotected intercourse on these days. Efficacy of these methods may be improved if the users most likely to engage in unprotected intercourse on fertile days can be identified and counseled.
\end{abstract}

METHODS: Quantitative and qualitative data from efficacy studies of the Standard Days Method ${ }^{\circledR}$ and the TwoDay Method ${ }^{\circledR}$ of family planning, in which 928 women each contributed up to 13 cycles of method use, were examined. Multinomial logit analysis was used to compare characteristics of women who occasionally had unprotected intercourse on fertile days with those who consistently used their method correctly. The reasons participants gave for having unprotected intercourse on fertile days were also examined.

RESULTS: Only 23\% of women had unprotected intercourse on their fertile days in one or more of the cycles they contributed to the study. The method and study site appear to have the most significant effect on correct use. Earning an income was associated with increased odds of unprotected intercourse on fertile days; higher quality of housing was associated with decreased odds. The results confirm the importance of partner cooperation for correct method use.

CONCLUSION: There was no clear profile of clients for whom these family planning methods would be inappropriate. However, programs offering these methods may help couples overcome potential difficulties in correct method use by including male partners and encouraging their participation in counseling sessions.

International Family Planning Perspectives, 2006, 32(2):94-100
Fertility awareness-based methods of family planning help women identify the days of their menstrual cycle on which they are fertile. Although intercourse on fertile days does not always result in pregnancy, the probability of pregnancy is high; ${ }^{1}$ women who wish to prevent pregnancy are instructed to avoid intercourse or use a barrier method as protection on those days.

A substantial number of women worldwide-as many as $20 \%$ of married women of reproductive age in some settings-report currently using a fertility-awareness approach to family planning (often referred to in surveys as "periodic abstinence"). ${ }^{2}$ Research indicates, however, that many of these women lack correct knowledge of when during their menstrual cycle they are most likely to become pregnant. They simply avoid unprotected intercourse on certain days of the cycle, without accurate information about how to determine when they are fertile. ${ }^{3}$ Many women prefer this approach to family planning because it does not have side effects or health risks and because it is inexpensive. In some settings, women prefer it because it conforms to religious or moral beliefs. ${ }^{4}$

Two fertility awareness-based methods of family planning-the Standard Days Method ${ }^{\circledR}$ and the TwoDay Method $^{\circledR}$-provide women with simple, clear instructions for identifying fertile days. The Standard Days Method can be used by women who have regular menstrual cycles that range from 26 to 32 days. This method requires women to avoid unprotected intercourse on days 8-19 of their cycle to prevent pregnancy. ${ }^{5}$ For the TwoDay Method, women observe the presence or absence of cervical secretions by examining toilet paper or underwear or by monitoring their physical sensations. Every day, a user answers two simple questions: "Did I note any secretions yesterday?" and "Did I note any secretions today?" If the answer to either question is yes, she considers herself fertile and avoids unprotected intercourse to prevent pregnancy. If the answer to both questions is no-that is, if she has had at least two consecutive days with no noticeable secretions of any typethe woman is unlikely to become pregnant from unprotected intercourse on that day. ${ }^{6}$

Because the possibility of pregnancy is so high on fertile days, it is important that programs help women to decide whether they are likely to use the method correctly. However, little research has been done to identify characteristics that might predict whether a woman is a good candidate for these methods.

The few studies on compliance with instructions for use of fertility awareness-based methods suggest that marital cooperation and communication between the partners are important determinants of correct use, as is the degree of satisfaction of the husband with the method. ${ }^{7}$ Factors associated with fewer unplanned pregnancies include older 
age, more education, ${ }^{8}$ and previous use of family planning methods ${ }^{9}$ or oral contraceptives. ${ }^{10}$ Also relevant is the couple's intention to delay their next pregnancy or not have any more children, which is highly correlated with parity. ${ }^{11}$ The degree of intention-measures of wantedness based on women's feelings about a potential pregnancy-also affects compliance, ${ }^{12}$ couples with a stronger intention to avoid pregnancy are more likely to comply with method use rules.

When compared with married women, unmarried women are less likely to use contraceptives correctly and consistently. ${ }^{13}$ A study of barrier method users found relationship characteristics, such as length of union and the presence of physical or sexual violence, to be important influences on consistent condom use ${ }^{14}$-couples in stable relationships are more likely to use condoms correctly and consistently than those in unstable unions involving infrequent or irregular intercourse.

Moos confirms that knowledge of correct contraceptive method use is positively associated with appropriate use; however, other factors, such as reservations about the method itself, lack of partner cooperation, and the woman's beliefs about her fertility may attenuate the effect of knowledge. ${ }^{15}$ Several personal characteristics appear to influence correct and consistent contraceptive use. Among them are age, ${ }^{16}$ race or ethnicity, ${ }^{17}$ religion ${ }^{18}$ and income level. ${ }^{19}$ However, the impact of these factors and the direction of their effect on compliance with method rules is not consistent across populations or cultures.

Rosenberg and colleagues ${ }^{20}$ found that women who lacked an established pill-taking routine were less likely to use oral contraceptives correctly. Establishing a daily routine may also be helpful to users of the Standard Days and TwoDay Methods as each method requires daily action.

In the present study, we attempt to identify characteristics that could predict which users are most likely to use fertility awareness-based methods incorrectly. Using data from the efficacy trials of the Standard Days Method and the TwoDay Method in 10 sites in four countries, we compare the characteristics of couples who used their method correctly with those who sometimes had unprotected intercourse on fertile days. We also examine the circumstances in which couples who had expressed the intention of avoiding pregnancy had unprotected intercourse during their fertile days.

\section{DATA AND METHODS}

In the Standard Days Method efficacy trial, 478 women participated at five sites in Bolivia, Peru and the Philippines; 450 women at five sites in Guatemala, Peru and the Philippines participated in the TwoDay Method efficacy trial. One of the requirements for participation in either study was the expressed wish to avoid pregnancy for at least a year. Study participants were made aware that the probability of pregnancy was much higher if they had unprotected intercourse during the days their method helped them to identify as fertile. Participants in both studies were followed for up to 13 cycles of method use, contributing almost 8,000 cycles to the studies. ${ }^{21}$ Overall, participants reported un- protected intercourse on fertile days in $3.4 \%$ of cycles (3\% for the Standard Days Method and 3.9\% for the TwoDay Method). However, $58 \%$ of the 90 pregnancies that occurred in the two studies combined occurred in cycles with unprotected intercourse (56\% in the Standard Days Method study and $60 \%$ in the TwoDay Method study). ${ }^{22}$

The study sites were diverse. The Standard Days Method study was conducted in Trinidad, Bolivia, a commercial center in the jungle; a squatter settlement in Lima, Peru; Juliaca, Peru, a commercial Andean city; La Trinidad, Philippines, a small city with well-developed infrastructure; and Tuba, Philippines, a municipality consisting of small villages. In Trinidad, Juliaca and La Trinidad, some participants lived in the urban center itself, and others in semirural clusters around it. The TwoDay Method study sites in Guatemala, Peru and the Philippines also varied. The Guatemala site, Totonicapan, consists of rural, indigenous Mayan communities. In Peru, the study sites were Iquitos, a commercial and transportation hub that is the largest city in the Peruvian Amazon, and Piura, a city in the coastal plains. In the Philippines, participants came from the small town of Alfonso and the surrounding villages, and Valenzuela, a working-class city that is part of Metro Manila.

The Standard Days Method and the TwoDay Method require that women have no unprotected intercourse during their fertile days. However, to obtain a clearer measure of method efficacy, the researchers asked participants to avoid sexual intercourse altogether during these days. The participants were also asked to note in a coital log any instances in which they had intercourse during the fertile days and any instances in which they used a backup method. The cycles the participants monitored can be divided into three groups: those in which women abstained during their fertile days; those in which women used a barrier method or withdrawal during their fertile days*; and those in which women had unprotected intercourse during their fertile days. Even though both of the first two groups represent correct use, we distinguish between them because we do not know if participants who used a barrier method or withdrawal when they had intercourse on a fertile day did so because they correctly understood how their method worked or because they chose not to comply with the requirements of the study.

Women in both studies were interviewed at the end of each cycle; those who reported unprotected intercourse during the fertile days of any cycle were asked why they had had unprotected intercourse.

Standard Days Method users reported a mean of 5.5 days with intercourse per cycle; for TwoDay Method users, this figure was 5.6. Women may have underreported intercourse, especially on fertile days, and may also have underreported use of backup methods (barrier or withdrawal). However, the mean coital frequencies reported by participants in both studies are quite similar to those reported in pub-

* Women were asked to report if they used another method, but not which method they used, so we cannot distinguish between barrier method use and withdrawal. 


\begin{tabular}{|c|c|c|c|}
\hline Characteristic & All & $\begin{array}{l}\text { Standard } \\
\text { Days } \\
\text { Method }\end{array}$ & $\begin{array}{l}\text { TwoDay } \\
\text { Method }\end{array}$ \\
\hline \multicolumn{4}{|l|}{ MEANS +} \\
\hline Mean age & $29.3(5.392)$ & $29.4(5.494)$ & $29.2(5.286)$ \\
\hline Mean age of partner & $33.0(6.833)$ & $33.0(6.625)$ & $33.0(7.053)$ \\
\hline Mean no. of children & $2.5(1.585)$ & $2.5(1.685)$ & $2.5(1.473)$ \\
\hline Mean age of & & & \\
\hline youngest child & $3.2(2.776)$ & $3.3(2.801)$ & $3.1(2.747)$ \\
\hline Housing quality index $\neq$ & $4.1(0.729)$ & $3.9(0.660)$ & $4.4(0.714)$ \\
\hline \multicolumn{4}{|l|}{ PERCENTAGES } \\
\hline Reads well & 86.2 & 91.0 & 81.1 \\
\hline Reads with difficulty & 10.4 & 8.2 & 12.7 \\
\hline \multicolumn{4}{|l|}{ Occupation } \\
\hline White-collar job & 9.8 & 8.9 & 10.5 \\
\hline Blue-collar job & 15.5 & 15.3 & 15.6 \\
\hline Sales & 22.0 & 18.3 & 25.9 \\
\hline Agriculture & 3.3 & 5.5 & 0.9 \\
\hline $\begin{array}{l}\text { No income-earning } \\
\text { occupation }\end{array}$ & 49.4 & 51.9 & 47.8 \\
\hline \multicolumn{4}{|c|}{ Ever-use of family planning method } \\
\hline IUD & 11.8 & 12.8 & 10.7 \\
\hline Hormonal method & 35.0 & 30.0 & 41.8 \\
\hline Barrier method & 29.8 & 30.8 & 28.9 \\
\hline Withdrawal & 34.4 & 37.0 & 31.8 \\
\hline $\begin{array}{l}\text { Periodic abstinence } \\
\text { Lactation }\end{array}$ & 49.5 & 55.9 & 42.2 \\
\hline amenorrhea method & 3.7 & 1.3 & 6.4 \\
\hline None & 14.9 & 9.6 & 20.7 \\
\hline
\end{tabular}

lished studies based on Demographic and Health Survey data in 32 countries throughout the world-5.5 monthly acts of intercourse for all sexually active married women, and 5.1 acts of intercourse per month for users of coitus-dependent methods. ${ }^{23}$

Almost identical procedures were followed in all study sites in both studies for recruitment of clients, counseling on the method and follow-up, with one important exception-Standard Days Method clients in Lima were recruited through door-to-door canvassing by research staff who were not their health providers; clients in all other sites were recruited when they came to a health facility to obtain a family planning method, or during home visits by health personnel. In general, fertility awareness-based methods were offered to the women as one choice among all family planning methods available. Women who showed an interest in these methods were asked to participate in the studies. In Lima, recruiters asked women if they were interested in fertility awareness-based methods; if the woman was interested in another method, she was referred to an area clinic. Service-system characteristics differed between sites. Services were offered in both public and private facilities, and by a range of providers, including midwives, nurses and community health workers.

* Information for some cycles is missing for three women, who are therefore excluded from the analysis.

\section{Statistical Analysis}

In the bivariate analysis, we examined the frequency of rule breaking and of pregnancies. Multinomial logit regression was used to compare the characteristics of women with at least one occurrence of intercourse with no backup protection (barrier method or withdrawal) on a day identified as fertile, women who had intercourse on their fertile days at least once but used condoms or withdrawal on these occasions and women who reported no intercourse at all on fertile days in any cycle they contributed to the study.

We also control for the effect of the varying service systems by including control variables for the country and the study. Because the Standard Days Method and the TwoDay Method have no physical side effects that could lead to inconsistent use, the multivariate analysis focuses on user characteristics, including age, parity, age of youngest child, housing characteristics (as a proxy for income), literacy (as a marker for education), occupation and ever-use of family planning. We exclude some characteristics that the literature suggests may affect user compliance with family planning methods in some settings: We exclude religion because all but three participants were Christian (77\% Catholic), marital status because all participants were living in union, and knowledge of correct method use because it was uniformly high in both studies. The interviewers did not collect information on whether women established a routine for the required daily action-moving the CycleBeads ${ }^{\circledR}$ ring at the same time each day for Standard Days Method users (CycleBeads is a string of color-coded beads that tracks users' cycle days and helps them to monitor their cycle length) or observing their cervical secretions for TwoDay Method users. In addition, we exclude information on marital cooperation and communication because it was collected through qualitative methods and therefore does not lend itself to quantitative statistical analysis.

\section{RESULTS}

Table 1 shows selected characteristics of the women who participated in the two studies. On average, participants were 29 years old; their partners' mean age was 33 . They had 2.5 children, and the youngest child was a little over three years old. The great majority were literate, and half had an income-earning occupation. Periodic abstinence was the most common previously used form of family planning.

Most couples did not have intercourse during the days that their method identified as fertile. Overall, 559 women (61\%) reported no intercourse on their fertile days in any of their cycles in the studies; the remaining 354 women reported having intercourse on their fertile days in at least one cycle-Table 2. Of these, 212 women (23\% of study participants) reported unprotected intercourse on a fertile day in at least one cycle. * None of the couples who had intercourse during the woman's fertile days did so habitually. Of women who contributed at least six cycles to the studies, only six women (1\%) had unprotected intercourse during their identified fertile days in a quarter or more of their cycles (not shown). 
Out of 7,963 cycles in the two studies, couples had intercourse on the fertile days in only 563 cycles; a barrier method or withdrawal was used as backup in 290 of those cycles and intercourse was unprotected in the 273 cycles.

There were no significant differences in the demographic characteristics of women in the three groups. However, literacy level and prior family planning use differed across groups. Less literate women reported abstinence on the fertile days more frequently than women who read well. Women who had never before used a family planning method of any kind often reported abstinence during the fertile days and rarely used a barrier method or withdrawal on these days, while women who had used family planning methods in the past reported using a backup method on the fertile days more frequently.

The behavior of participants also varied across study sites. Women in Lima used another method during the fertile days on more occasions than other women; women in Totonicapan and Tuba rarely reported using another method.

Multinomial logit analysis confirms that the study, study sites and past use of certain contraceptive methods were associated with how well women used their method (Table 3, page 98). Women who participated in the TwoDay Method study were significantly less likely than those in the Standard Days Method study to use their method correctly. Participants in Peru and the Philippines were significantly less likely than those in other sites to use the methods correctly.

When we compare women who reported no intercourse on fertile days in any of their cycles with women who reported unprotected intercourse on their fertile days in at least one cycle, housing quality and having an income-earning occupation have statistically significant effects. Women who had an income-generating occupation were less likely to abstain on the fertile days (odds ratio 0.7). Women with higher housing quality were more likely to abstain than to have unprotected intercourse on their fertile days (odds ratio 1.5).

Women who had used a barrier method, withdrawal or some form of periodic abstinence in the past were twice as likely to have used a backup method as to have had unprotected intercourse on their fertile days.

\section{Reasons for Unprotected Intercourse}

Of the 212 women who had unprotected intercourse on a fertile day, most (76\%) did so in only one cycle in the study. Only 51 women had unprotected intercourse on a fertile day in two or more cycles (maximum five). We include here only their responses from the first such cycle, to prevent bias.

Only 81 (38\%) of the women who reported having had unprotected intercourse on a fertile day in at least one cycle gave a reason. This information was rarely provided spontaneously, and providers reported feeling uncomfortable probing this issue; the sensitive nature of this information may influence the reliability of responses.

Of the women who reported their reason for having unprotected intercourse on a fertile day, 39 had done so because their husbands insisted. Most of them did not explicitly ex-
TABLE 2. Means (and standard deviations) and percentage distribution of women
using the Standard Days and TwoDay Methods, by sexual activity and use of backup method on fertile days, according to selected characteristics

\begin{tabular}{|c|c|c|c|c|}
\hline Characteristic & $\begin{array}{l}\text { No intercourse } \\
(\mathrm{N}=559)\end{array}$ & $\begin{array}{l}\text { Intercourse } \\
\text { With barrier } \\
\text { method or } \\
\text { withdrawal } \\
(\mathrm{N}=142)\end{array}$ & $\begin{array}{l}\text { Unprotected }+ \\
(\mathrm{N}=212)\end{array}$ & Total \\
\hline Mean age & $29.3(5.478)$ & $29.1(5.215)$ & $29.6(5.183)$ & na \\
\hline Mean age of partner & $33.0(6.922)$ & $33.0(7.104)$ & $32.9(6.414)$ & na \\
\hline $\begin{array}{l}\text { Mean no. of children } \\
\text { Mean age of }\end{array}$ & $3.0(2.716)$ & $3.6(2.895)$ & $3.4(2.830)$ & na \\
\hline youngest child & $2.8(2.655)$ & $3.5(2.885)$ & $3.1(2.781)$ & na \\
\hline Housing quality index $\neq$ & $4.1(0.715)$ & $4.1(0.681)$ & $4.1(0.796)$ & na \\
\hline \multicolumn{5}{|l|}{ Literacy } \\
\hline Reads well & 58.4 & 16.6 & 24.9 & 100.0 \\
\hline Reads with difficulty & 76.6 & 9.7 & 13.7 & 100.0 \\
\hline \multicolumn{5}{|l|}{ Occupation§ } \\
\hline White-collar job & 56.2 & 16.9 & 27.0 & 100.0 \\
\hline Blue-collar job & 46.7 & 25.5 & 27.7 & 100.0 \\
\hline Sales & 65.2 & 13.1 & 21.7 & 100.0 \\
\hline Agriculture & 63.3 & 3.3 & 33.3 & 100.0 \\
\hline \multicolumn{5}{|l|}{ No income-earning } \\
\hline occupation & 65.1 & 14.2 & 20.8 & 100.0 \\
\hline \multicolumn{5}{|c|}{ Ever-use of family planning method } \\
\hline IUD & 50.0 & 26.9 & 23.1 & 100.0 \\
\hline Hormonal method & 49.7 & 22.2 & 28.1 & 100.0 \\
\hline Barrier method & 51.1 & 25.0 & 23.9 & 100.0 \\
\hline Withdrawal & 51.9 & 22.2 & 25.9 & 100.0 \\
\hline Periodic abstinence & 58.4 & 20.4 & 21.2 & 100.0 \\
\hline Lactation & & & & \\
\hline amenorrhea method & 52.9 & 17.6 & 29.4 & 100.0 \\
\hline None & 77.0 & 5.8 & 17.3 & 100.0 \\
\hline \multicolumn{5}{|l|}{ Study } \\
\hline Standard Days Method & 61.5 & 17.7 & 20.8 & 100.0 \\
\hline TwoDay Method & 61.0 & 13.2 & 25.8 & 100.0 \\
\hline \multicolumn{5}{|l|}{ Study site } \\
\hline \multicolumn{5}{|l|}{ Standard Days Method } \\
\hline Trinidad, Bolivia & 64.8 & 18.5 & 16.7 & 100.0 \\
\hline Juliaca, Peru & 63.7 & 18.6 & 17.6 & 100.0 \\
\hline Lima, Peru & 37.0 & 40.0 & 23.0 & 100.0 \\
\hline \multicolumn{5}{|l|}{ La Trinidad, } \\
\hline Philippines & 57.8 & 9.8 & 32.4 & 100.0 \\
\hline Tuba, Philippines & 82.1 & 4.3 & 13.7 & 100.0 \\
\hline \multicolumn{5}{|l|}{ TwoDay Method } \\
\hline Totonicapan, Guatemala & 87.8 & 3.4 & 8.8 & 100.0 \\
\hline Iquitos, Peru & 44.7 & 17.0 & 38.3 & 100.0 \\
\hline Piura, Peru & 52.6 & 17.5 & 29.9 & 100.0 \\
\hline Alfonso, Philippines & 56.6 & 11.3 & 32.1 & 100.0 \\
\hline \multicolumn{5}{|l|}{ Valenzuela, } \\
\hline Philippines & 30.4 & 30.4 & 39.1 & 100.0 \\
\hline
\end{tabular}

tIncludes 202 women who reported intercourse with a backup method in at least one cycle, but also reported unprotected intercourse in at least one cycle. fIndex was calculated from information on source of water, availability of electricity and material used for cooking. In the Standard Days Method study, it also includes main wall material; in the TwoDay Method study, it also includes floor material. The index is a continuous variable ranging from 1.5 to 5.0 . §Not tested for significance because of small cell size. Note: na=not applicable.

plain how their husband insisted, but three women said their husband convinced them that they could not get pregnant if they had intercourse just once, and 11 said that their husband was drunk. Eighteen women stated that they had unprotected intercourse on a fertile day because the fertile period was too long, making it difficult to comply. Fifteen women reported difficulty in following the daily routine involved in using their method or in identifying the fertile days. Standard Days Method users forgot to move the ring, or did not 


\begin{tabular}{|c|c|c|}
\hline \multirow[t]{2}{*}{ Characteristic } & $\begin{array}{l}\text { No intercourse } \\
(\mathrm{N}=531)\end{array}$ & $\begin{array}{l}\text { Intercourse } \\
\text { with backup } \\
\text { method } \dagger \\
(\mathrm{N}=127)\end{array}$ \\
\hline & Odds ratio & Odds ratio \\
\hline Age & 1.00 & 0.96 \\
\hline No. of children & 1.16 & 1.25 \\
\hline Age of youngest child & 0.96 & 1.18 \\
\hline Housing quality index & $1.46^{* *}$ & 1.36 \\
\hline Reads well & 0.66 & 0.80 \\
\hline Earns income & $0.68^{* *}$ & 0.97 \\
\hline \multicolumn{3}{|c|}{ Ever-use of family planning method } \\
\hline Never used (ref) & 1.00 & 1.00 \\
\hline IUD or hormonal method & 0.72 & 1.43 \\
\hline Barrier method & 1.08 & $1.98^{* *}$ \\
\hline Withdrawal or periodic abstinence & 1.25 & $2.03^{* *}$ \\
\hline \multicolumn{3}{|l|}{ Country } \\
\hline Guatemala and Bolivia (ref) & 1.00 & 1.00 \\
\hline Peru & $0.25^{* *}$ & 0.55 \\
\hline Philippines & $0.23^{* *}$ & $0.37^{*}$ \\
\hline Uses TwoDay Method & $0.51^{* *}$ & $0.45^{* *}$ \\
\hline
\end{tabular}

have their CycleBeads at hand when they needed to determine whether they were fertile. TwoDay Method users forgot to check for secretions or were not sure of their fertility status. Nine women simply decided to take a chance.

\section{DISCUSSION}

Most users of the Standard Days Method or the TwoDay Method reported having no problem avoiding unprotected intercourse on their fertile days. Couples who had unprotected intercourse on their fertile days did so only occasionally. However, because cycles with unprotected intercourse on the fertile days are so much more likely to result in pregnancy, the efficacy of the methods can be improved significantly with even a moderate reduction in the occurrence of unprotected intercourse on the fertile days.

We expected to find individual characteristics that predicted the likelihood of having intercourse on fertile days. If clients who are more likely to break the rules of their method could be identified, providers could adapt their counseling to help these women cope with whatever difficulty is prompting them to have intercourse on their fertile days despite their intention to avoid pregnancy or could recommend that such women use a different method. But we could not identify such clients.

Only two individual characteristics predicted having unprotected intercourse on the fertile days rather than abstaining. The first is the housing quality index-women who scored higher on this index were more likely to use the methods correctly than were those who did not. The stress associated with poverty may be a factor in incorrect method use; when efforts and energy need to be focused on immediate problems of daily survival, it may be hard to think about long-term goals and future consequences of actions.
The other variable that predicted which women had had unprotected intercourse was having an income-generating occupation. Women who worked outside the home were less likely than those who did not to use their method correctly. Although modern fertility awareness-based methods are often used by more educated women, periodic abstinence-which uses untested, traditional rules to identify the fertile period-is often used by women who have a more traditional profile. These women may have less exposure to modern contraceptive methods and a higher commitment to using a natural family planning method. ${ }^{24}$ Women who do not work outside the house may be more traditional; they may be more committed to the method and more opposed to other methods, and therefore more likely to use their fertility awareness-based method correctly.

The method a woman was using, and the country in which the study took place, were also highly significant predictors of how well she used her method. Standard Days Method study participants were more likely than participants in the TwoDay Method study to avoid unprotected intercourse on their fertile days. Several method and study characteristics may have contributed to this effect.

First, with the Standard Days Method, the fertile period always starts on day 8 and always ends on day 19 of a woman's cycle. The woman and her partner know exactly what to expect each cycle and can plan accordingly. The TwoDay Method, on the other hand, requires more flexibility and is a less clear-cut way of determining which days are fertile. In most cycles, secretions started between days 6 and 11, but couples using the method needed to be prepared for secretions to start any day, and once secretions started they did not know exactly when the last day of secretions would be. In addition, women may have to make subjective judgments about whether they have secretions. This uncertainty may have affected correct method use.

Second, users of the Standard Days Method often use CycleBeads to keep track of their cycle days. CycleBeads also serve as a visual reminder to husbands about their wife's fertile days. Further, the husband can take an active role in method use if he is the one moving the ring on the beads each day. Although participants in the TwoDay Method study completed a diary card on which they marked their fertile days, couples needed to communicate more explicitly about the days on which they should avoid unprotected intercourse to prevent pregnancy, and men could not take such an active role in method use.

In spite of the method's inherent variability, most women using the TwoDay Method knew more or less when to expect their first day of secretions after the first few cycles. Similarly, women and their partners quickly learned in general how many fertile days to expect each cycle. Communication between partners also improved with subsequent cycles of method use. It is not surprising, therefore, that within three months of beginning method use, as couples adjusted to their method, the incidence of unprotected intercourse decreased for both methods, but in particular for TwoDay Method users. ${ }^{25}$ 
Finally, the methods were offered in different studies. The data may reflect different providers offering different methods to different populations at different times.

The study country was also associated with how well women used their method. With method controlled, participants at sites in the Philippines and in Peru were less likely to use the method correctly than participants at sites in Bolivia and Guatemala.

In the casa of Lima, participants were recruited through a door-to-door census; unlike the women at the other study sites, they were not actively seeking a family planning method at the time. It is possible, therefore, that they were less motivated to prevent pregnancy.

Lima and La Trinidad, the Standard Days Method study sites with the highest percentage of women who had unprotected sex on fertile days, are also the most urbanized sites. In the TwoDay Method study, incorrect use was also highest in the more urban sites. This suggests that improved counseling is needed in urban areas.

Couples with previous experience with barrier method use were more likely to use such a method on their fertile days than to have unprotected intercourse. Sites may vary in the availability of barrier methods, in their acceptability to users and providers, and in the comfort and skill of providers in offering them. If the nature of the service delivery program and the preferences of potential method users make it feasible, providers could be trained to offer barrier methods and include information on how to use them in counseling on fertility awareness-based methods.

Although we attempted to standardize method provision across settings, differences among countries and sites in contraceptive prevalence, availability and acceptability of other contraceptive options, provider commitment to informed choice and quality of counseling in other contraceptive methods were inevitable. Our interactions with clients and providers in the study sites suggest that some cultural differences that affect the probability of correct method use are not reflected in the variables in our analyses. Also, the economic and other implications of having an additional child may differ across sites, affecting couples' degree of commitment to avoiding pregnancy. Men views about family planning use, and their attitudes toward abstinence and barrier methods, may also vary.

Many women who had unprotected intercourse during their fertile days said they did so because their husbands insisted. Partner support and cooperation is necessary for correct use of fertility awareness-based methods of family planning. Counseling both partners, not just the woman, in the use of the Standard Days Method and the TwoDay Method may be helpful. Studies that introduced the Standard Days Method in various countries and settings found that correct method use was enhanced by counseling men and women together, providing the woman with written information on the method to share with her husband and providing informational sessions for men in the community. ${ }^{26}$

The data were collected as part of efficacy studies, and were not designed to examine the situations leading to cor- rect and incorrect use. As a result, the data are limited, and only $38 \%$ of participants who reported unprotected intercourse at least once during the study period provided a reason for this behavior. Another limitation of the study is the study requirement of abstinence during the fertile period, which is different from the instruction users receive when the method is offered in regular service delivery (normally, users are told to abstain or use a barrier method).

Programs offering the Standard Days Method and the TwoDay Method should train providers not only to instruct clients in correct method use, but also to help them learn negotiating skills. Providers should make sure that women understand the consequences of having intercourse on fertile days and, if possible, involve men in the counseling.

\section{REFERENCES}

1. Trussell J and Grummer-Strawn L, Contraceptive failure of the ovulation method of periodic abstinence, Family Planning Perspectives, 1990, 22(2):65-75

2. Curtis SL and Neitzel K, Contraceptive Knowledge, Use and Sources, Demographic and Health Surveys Comparative Studies, Calverton, MD: Macro International, 1996, No. 19.

3. National Statistical Office, Philippines National Demographic and Health Survey 2003, Calverton, MD: Macro International, 2004.

4. Labbok MH, Klaus $\mathrm{H}$ and Barker D, Factors related to ovulation method efficacy in three programs: Bangladesh, Kenya, and Korea, 1988, Contraception, 37(6):577-589.

5. Arévalo M, Sinai I and Jennings V, A fixed formula to define the window of the menstrual cycle as the basis of a simple method of natural family planning, 2000, Contraception, 60(6):357-360.

6. Sinai I, Jennings V and Arévalo M, The TwoDay Algorithm: a new algorithm to identify the fertile time of the menstrual cycle, 1999, Contraception, 60(2):65-70.

7. Sharma RK, Psychosocial factors in natural family planning: an overview, in: Queenen JT et al., eds., Natural Family Planning: Current Knowledge and New Strategies for the 1990s, Part II, Washington, DC: Georgetown University, 1992, pp. 115-117; and World Health Organization, A prospective multicenter trial of the ovulation method of natural family planning. V. Psychosexual aspects, 1987, Fertility and Sterility, 47(5):765-772.

8. France MM, Psychosexual aspects of natural family planning as revealed in the World Health Organization multicenter trial of the ovulation method and the New Zealand Continuation Study, in: Queenen JT et al., eds., Natural Family Planning: Current Knowledge and New Strategies for the 1990s, Part II, Washington, DC: Georgetown University, 1992, pp. 118-120; and Labbok MH, Klaus H and Barker D, 1988, op. cit. (see reference 4).

9. Labbok MH, Perez A and Klaus H, A profile of successful vs. unsuccessful ovulation method users: factors associated with unplanned pregnancy and nonadherence to the rules, in: Queenen JT et al., eds., Natural Family Planning: Current Knowledge and New Strategies for the 1990s, Part II, Washington, DC: Georgetown University, 1992, pp. 121-123.

\section{Ibid.}

11. Labbok MH, Perez A and Klaus H, 1992, op. cit. (see reference 9); and Sharma RK, 1992, op. cit. (see reference 7).

12. Miller WB and Pasta DJ, Behavioral intentions: which ones predict fertility behavior in married couples? Journal of Applied Social Psychology, 1995, 25(6):530-555.

13. Potter L et al., Measuring compliance among oral contraceptive users, Family Planning Perspectives, 1996, 28(4):154-158.

14. Beckman LJ and Harvey SM, Factors affecting the consistent use of barrier methods of contraception, Obstetrics \& Gynecology, 1996, 88(3 Suppl.):65S-71S.

15. Moos MK, Bartholomew NE and Lohr KN, Counseling in the clin- 
ical setting to prevent unintended pregnancy: an evidence-based research agenda, Contraception, 2003, 67(2):115-132.

16. Cramer JA, Compliance with contraceptives and other treatment, Obstetrics \& Gynecology, 1996, 88(3 Suppl.):4S-12S; and Deblanco SF, Improving the use of contraceptives: the challenge continues, Obstetrics E Gynecology, 1996, 88(3 Suppl.):1S-3S.

17. Potter L et al., 1996, op. cit. (see reference 13).

18. Khan MA, Trottier DA and Islam MA, Inconsistent use of oral contraceptives in rural Bangladesh, Contraception, 2002, 65(6):429-433.

19. Peterson LS et al., Women's efforts to prevent pregnancy: consistency of oral contraceptive use, Family Planning Perspectives, 1997, 30(1) $19-23$

20. Rosenberg MJ, Waugh MS and Burnhill MS, Compliance, counseling and satisfaction with oral contraceptives: a prospective evaluation, Family Planning Perspectives, 1998, 30(2):89-92 \& 104

21. Arévalo M, Jennings V and Sinai I, Efficacy of a new method of family planning: the Standard Days Method, 2002, Contraception, 65(5): 333-338; and Arévalo M et al., Efficacy of the new TwoDay Method of family planning, 2004, Fertility and Sterility, 82(4):885-892.

22. Ibid.

23. Moos MK, Bartholomew NE and Lohr KN, 2003, op. cit. (see reference 15)

24. Choque ME, Rance S and Schuler SR, Misinformation, mistrust, and mistreatment: family planning among Bolivian market women, 1994, Studies in Family Planning, 25(4):111-121; and Goldberg HI and Toros A, The use of traditional methods of contraception among Turkish couples, 1994, Studies in Family Planning, 25(2):122-128.

25. Sinai I and Arévalo M, It's all in the timing: coital frequency and fertility awareness-based methods of family planning, Journal of Biosocial Science, (forthcoming)

26. Lundgren RI et al., Cultivating men's interest in family planning in rural El Salvador, 2005, Studies in Family Planning, 36(3):173-188.

\section{RESUMEN}

Contexto: Los métodos de planificación familiar que dependen de la conciencia de la propia fertilidad ayudan a que las mujeres identifiquen los días de su ciclo menstrual durante los cuales tienen mayores probabilidades de quedar embarazadas. Para prevenir el embarazo, las mujeres deben evitar durante esos días mantener relaciones sexuales sin protección. Se puede mejorar la eficacia de estos métodos si se puede identificar y aconsejar a las usuarias que tienen las mayores probabilidades de mantener relaciones sexuales sin protección en sus días fértiles. Métodos: Se examinaron los datos cuantitativos y cualitativos de estudios sobre la eficacia de dos métodos de planificación familiar, el Método de Días Fijos ${ }^{\circledR}$ y el Método de Dos Días ${ }^{\circledR}$. Se participaron en los estudios 928 mujeres y cada una contribuyó con el uso de hasta 13 ciclos. Se utilizaron técnicas de análisis de logit multinomial para comparar las características de las mujeres que ocasionalmente mantenían relaciones sexuales en sus días fértiles con aquellas que siempre utilizaban su método en forma correcta. También se examinaron las razones que esgrimían las participantes por haber mantenido relaciones sexuales sin protección durante sus días fértiles.

Resultados: Solamente el 23\% de las mujeres habian mantenido relaciones sexuales sin protección durante sus dias fértiles en uno o más de los ciclos que contribuyeron para los datos. El método específico y el lugar del estudio parecen tener el efecto más significativo con respecto al uso correcto del método. Tener ingresos estuvo relacionado con unas probabilidades mayores de haber tenido relaciones sexuales sin protección durante los días fértiles; una mayor calidad de la vivienda estuvo relacionada con menores probabilidades. Los resultados confirman la importancia de la cooperación de la pareja para usar el método correctamente.

Conclusión: No se estableció un perfil claro de las clientas que no serían apropiadas para el uso de estos métodos. Además, por incluir al cónyuge y alentar su participación en las sesiones de consejería, los programas que ofrecen estos métodos pueden ayudar a las parejas a superar las dificultades potenciales con respecto a su uso correcto.

\section{RÉSUMÉ}

Contexte: Les méthodes de planification familiale reposant sur la conscience de la fécondité aident les femmes à identifier les jours du cycle menstruel où la probabilité de grossesse est la plus élevée. Pour éviter la grossesse, les femmes évitent les rapports sexuels non protégés durant cette période. L'efficacité de ces méthodes peut être améliorée si les utilisatrices les plus susceptibles d'avoir des rapports sexuels non protégés durant leur période féconde peuvent être identifiées et conseillées.

Méthodes: Les données quantitatives et qualitatives d'études d'efficacité des méthodes de planification familiale Standard Days Method ${ }^{\circledR}$ et TwoDay Method ${ }^{\circledR}$, relatives à 928 femmes sur 13 cycles, au maximum, de pratique de la méthode, ont été examinées. L'analyse de logit multinomiale a servi à comparer les caractéristiques des femmes auxquelles il arrivait d'avoir des rapports sexuels non protégés en période féconde par rapport à celles qui pratiquaient rigoureusement la méthode. Les raisons données par les participantes à comportement irrégulier ont également été examinées.

Résultats: Seuls 23\% des femmes avaient eu des rapports sexuels non protégés en période féconde durant un ou plusieurs cycles de participation à l'étude. La méthode et le site d'étude semblent présenter l'effet le plus significatif sur l'usage correct. L'activité rémunératrice s'est révélée associée à une probabilité accrue de rapports non protégés en période féconde, tandis qu'une qualité de logement meilleure était associée à une probabilité moindre. Les résultats confirment l'importance de la coopération du partenaire à la pratique correcte de la méthode.

Conclusion: Aucun profil clair n'est apparu concernant les clientes pour lesquelles ces méthodes de planification familiale seraient inappropriées. Les programmes offrant ces méthodes pourraient cependant aider les couples à surmonter les difficultés potentielles d'usage correct de la méthode en incluant les partenaires de sexe masculin et en encourageant leur participation aux séances de conseil.

\section{Acknowledgments}

Support for the analysis and preparation of this article was provided by the Institute for Reproductive Health, Georgetown University, Washington, DC, which is funded under cooperative agreement HRN-A-00-97-00011-00 with the United States Agency for International Development (USAID). The views expressed by the authors do not necessarily reflect the views or policies of USAID or Georgetown University.

Author contact:irh@georgetown.edu 